\title{
IMPACT OF BICARBONATE CONTENT OF IRRIGATION WATER, FARMYARD MANURE AND SULPHUR ON WHEAT PRODUCTION AND AVAILABLE MICRONUTRIENTS
}

\author{
Alaga, M. D.
}

A. A. Mousa

*Soil Conservation Dept., Desert Res. Centre Cairo, Egypt

"* Soil Sci. Dept., Faculty of Agric., Moshtohor, Benha Univ., Egypt

\begin{abstract}
This study was carried out on a calcareous sandy loam soil at Sudr Research Station, South Sinai for conserving soil from the bicarbonate hazard in saline irrigation water. Four bicarbonate levels; 2.5, 5, 10 and $15 \mathrm{meqL}^{-1}$ in saline irrigation water were applied. Also, three farmyard manure rates $\left(0,10,20 \mathrm{~m}^{3} \mathrm{fed}^{-1}\right)$ and sulphure rates $(0$, 250 and $500 \mathrm{~kg} \mathrm{fed}^{-1}$ ) were applied individual and/or in combined. The organic manure and sulphure had positively significant effects on yield. The results also show that the highest value of grain and straw yields were obtained from $\left(\mathrm{HCO}_{3}\right)_{1} \mathrm{OM}_{2} \mathrm{~S}_{2}$ but the best treatment from economic point of view was $\left(\mathrm{HCO}_{3}\right)_{2} \mathrm{OM}_{1} \mathrm{~S}_{2}$. The highest values of available $\mathrm{Fe}^{++}, \mathrm{Mn}^{++}$and $\mathrm{Zn}^{++}$were found with $\mathrm{OM}_{2} \mathrm{~S}_{2}$ under all bicarbonate concentrations in saline irrigation water.

Keywords: Calcareous sandy loam soil, saline irrigation water, FYM, sulphur, wheat production and available micronutrients.
\end{abstract}

\section{INTRODUCTION}

In Egypt, calcareous soils represent about $25 \%$ of the new reclaimed area. Because of the limiting water supply, the need of expanding agricultural lands had to use saline water in irrigation which caused soil deterioration in some areas.

Mengel et al., (1984) interpreted the reduction in the yield of plant due to $\mathrm{HCO}_{3}$ to one or to more of the following reasons (a) the adverse effect of $\mathrm{HCO}_{3}$ on the plant metabolic processes, (b) the disturbance of the plant nutrient balance, (c) the excess of $\mathrm{HCO}_{3}$ induced the dominance of $\mathrm{CO}_{3}{ }^{--}$, ions which react with free soluble $\mathrm{Zn}$ in soil solution.

El-Shall et al., (1987) found that sulphur was referred to its influence on reducing soil $\mathrm{pH}$, improving soil structure and increasing the availability of certain nutrients.

Aich et al., (1997) stated that grain yield of wheat was decreased with increasing salinity of irrigation water in all three soils. Application of decomposed cow dung decomposed straw, gypsum or lime increased grain yield.

Clarck et al., (1999) mentioned that sorghum aerial plant and root production decreased with increasing salinity. Plant $\mathrm{Ca}, \mathrm{Sr}, \mathrm{Mn}$ and $\mathrm{Cd}$ levels increased with increasing salinity. In contrast, sorghum $\mathrm{K}, \mathrm{P}$, and $\mathrm{S}$ levels declined with increasing salinity.

The aim of the present work is to understand the interactions between bicarbonate, farmyard manure and sulphur. 


\section{MATERIALS AND METHODS}

A field experiment was carried out at Sudr Research Station, South Sinai, in split-split design. The field was divided into plots (1/400 fed), 3 X 3.5 $\mathrm{m}$. All treatments received constant rates, from NPK $\left(80,30\right.$ and $\left.48 \mathrm{~kg} \mathrm{fed}^{-1}\right)$ as $\mathrm{N}, \mathrm{P}_{2} \mathrm{O}_{5}$ and $\mathrm{K}_{2} \mathrm{O}$, respectively as form ammonium nitrate, super phosphate and potassium sulphate respectively. Farm yard manure and sulphur were applied at rates of $\left(0,10\right.$ and $\left.20 \mathrm{~m}^{3} \mathrm{fed}^{-1}\right)$ from FYM and 0,250 and $500 \mathrm{~kg} \mathrm{~S} \mathrm{fed}^{-1}$. The wheat seeds (Sakha 8) were cultivated through two seasons 1999/2000 and 2000/2001. Grain and straw yields were evaluated at harvesting. After harvesting of wheat plants, representative soil samples were taken from $0-15,15-30$ and $30-45 \mathrm{~cm}$ depths of each replicate to determine the soil chemical and physical properties under investigation. $\mathrm{O} . \mathrm{M} \%$, Soil $\mathrm{pH}$, EC, soluble cations and anions also ESP were determined according to Jackson (1967) and Chapman and Pratt (1961).

Table 1: Some physical properties of the experimental soils at Ras Sudr.

\begin{tabular}{|c|c|c|c|c|c|c|c|c|c|c|}
\hline \multirow{2}{*}{$\begin{array}{c}\text { Soil } \\
\text { depth } \\
\text { (cm) }\end{array}$} & \multicolumn{4}{|c|}{ Particle size distribution (\%) } & \multirow[b]{2}{*}{$\begin{array}{l}\text { Texture } \\
\text { class }\end{array}$} & \multirow{2}{*}{\begin{tabular}{|c|} 
Bulk \\
Density \\
$\left(\mathrm{g} \mathrm{cm}^{-3}\right)$
\end{tabular}} & \multirow{2}{*}{$\begin{array}{c}\text { Field } \\
\text { capacity } \\
(\%)\end{array}$} & \multirow{2}{*}{$\begin{array}{c}\text { Wilting } \\
\text { point } \\
\text { (\%) }\end{array}$} & \multirow{2}{*}{$\begin{array}{c}\text { Av. } \\
\text { water } \\
\text { (\%) }\end{array}$} & \multirow[b]{2}{*}{$\begin{array}{c}\mathrm{CaCO}_{3} \\
(\%)\end{array}$} \\
\hline & \begin{tabular}{|c|} 
Coarse \\
Sand
\end{tabular} & \begin{tabular}{|l} 
Fine \\
Sand
\end{tabular} & Silt & Clay & & & & & & \\
\hline $0-15$ & & & & & & 1.44 & & & 50.90 & \\
\hline & & & & & & & & & & \\
\hline $30-45$ & 37.40 & 42.22 & 3.10 & 7.28 & Sanc & 1.52 & 17.30 & 10.63 & 51.32 & 51.32 \\
\hline
\end{tabular}

Table 2: Some chemical properties of the experimental soils at Ras Sudr.

\begin{tabular}{|c|c|c|c|c|c|c|c|c|c|c|}
\hline \multirow{2}{*}{$\begin{array}{l}\text { Soil } \\
\text { depth } \\
(\mathrm{cm})\end{array}$} & \multirow[t]{2}{*}{$\mathrm{pH}$} & \multirow{2}{*}{$\begin{array}{c}E C \\
\left(\mathrm{dSm}^{-1}\right)\end{array}$} & \multicolumn{3}{|c|}{$\begin{array}{c}\text { Soluble cations } \\
\left(\mathrm{meqL}^{-1}\right)\end{array}$} & \multicolumn{4}{|c|}{$\begin{array}{c}\text { Soluble anions } \\
\left(\text { meq L }^{-1}\right)\end{array}$} & \multirow[t]{2}{*}{ ESP } \\
\hline & & & $\mathrm{Ca}^{+2}+\mathrm{Mg}^{+2}$ & $\mathrm{Na}^{+}$ & $\mathrm{K}^{+}$ & $\mathrm{CO}_{3}=$ & $\mathrm{HCO}_{3}{ }^{-}$ & $\mathrm{Cl}^{-}$ & $\mathrm{SO}_{4}=$ & \\
\hline $0-15$ & 7.4 & 14.3 & 97.71 & 79.80 & 0.01 & -- & 3.54 & 133.47 & 50.90 & 13.60 \\
\hline $15-30$ & 7.4 & & 0 & 82. & 0. & -- & 6.8 & 1.70 & 61 & 14.92 \\
\hline $30-45$ & 7.4 & 11.70 & 84.88 & 58.75 & 1.80 & -- & 5.16 & 74.97 & 51.32 & 10.75 \\
\hline
\end{tabular}

Well water analyses were determined as previously mentioned in soil extracts and are given in Table 3.

Table 3: Analyses of the saline well water used for irrigation.

\begin{tabular}{|c|c|c|c|c|c|c|c|c|}
\hline \multirow{2}{*}{$E C\left(d^{-1} ~ m^{-1}\right)$} & \multirow{2}{*}{\multicolumn{3}{|c|}{ Soluble cations $\left(\mathrm{meq} \mathrm{L}^{-1}\right)$}} & \multicolumn{4}{|c|}{ Soluble anions (meq $\mathrm{L}^{-1}$ ) } & \multirow{2}{*}{ SAR } \\
\hline & & & & $\mathrm{CO}_{3}=$ & $\mathrm{HCO}_{3}$ & $\mathrm{Cl}^{-}$ & $\mathrm{SO}_{4}=$ & \\
\hline 10.20 & 62.80 & 80.13 & 1.18 & -- & 2.50 & 81.90 & 39.60 & 10.70 \\
\hline
\end{tabular}

FYM analyses were determined according to Jackson (1967), Lindsay and Norvell (1978) and Frie et al., (1964). The obtained data are showed in Table 4.

Table 4: Analyses of the applied farmyard manure.

\begin{tabular}{|c|c|c|c|c|c|c|c|c|c|c|c|}
\hline \multirow[t]{2}{*}{$\begin{array}{c}E C \\
\left(\mathrm{dSm}^{-1}\right)\end{array}$} & \multirow[t]{2}{*}{ pH } & \multirow[t]{2}{*}{$\begin{array}{l}\text { O. C. } \\
(\%)\end{array}$} & \multirow{2}{*}{$\begin{array}{c}\text { Water } \\
\text { holding } \\
\text { capacity } \\
(\%)\end{array}$} & \multirow{2}{*}{$\begin{array}{c}\text { Total } \\
N \\
(\%)\end{array}$} & \multirow[t]{2}{*}{$\begin{array}{c}\mathrm{C} / \mathrm{N} \\
\text { (ratio) }\end{array}$} & \multirow[t]{2}{*}{$\begin{array}{c}\text { Total } \\
\mathbf{P} \\
(\%)\end{array}$} & \multirow[t]{2}{*}{$\begin{array}{c}\text { Total } \\
\text { K } \\
(\%)\end{array}$} & \multirow{2}{*}{$\begin{array}{c}\text { Total } \\
\text { sulphate } \\
(\%)\end{array}$} & \multicolumn{3}{|c|}{$\begin{array}{c}\text { Total } \\
\begin{array}{c}\text { micronutrients } \\
\left(\mathrm{mg} \mathrm{kg}^{-1}\right)\end{array} \\
\end{array}$} \\
\hline & & & & & & & & & $\mathrm{Fe}$ & $\mathrm{Mn}$ & $\mathrm{Zn}$ \\
\hline 34.9 & 7.3 & 20.3 & 180 & 1.52 & 13.4 & 0.92 & 1.48 & 1.24 & 212 & 127 & 98 \\
\hline
\end{tabular}


Finally, the statistical analysis of the obtained data was done according to the method described by Gomez and Gomez (1984) using LSD to compare the mean values of treatments.

\section{RESULTS AND DISCUSSION}

Data in Tables 5 and 6 reveal that grain and straw yields of wheat (ton fed $^{-1}$ ) were affected by the interaction between bicarbonate, organic manure and sulphur application during the two seasons. Table 5 shows that the effect of organic manure and sulphur was the best in case of $\mathrm{OM}_{2} \mathrm{~S}_{2}$ through the concentration of $5 \mathrm{meqL}^{-1}$ bicarbonate, while the same effect was in case of 10 meqL $^{-1} \mathrm{HCO}_{3}^{-3}$ less than $5 \mathrm{meqL}^{-1}$ where, the bicarbonate increased the deterious effect, while the more pronounced effects of FYM and S applications were noticed in the $1^{\text {st }}$ season.

Table 5: Grain yields of wheat (ton fed $^{-1}$ ) as affected by bicarbonate, organic manure and sulphur application during the two studied seasons.

\begin{tabular}{|c|c|c|c|c|c|c|c|c|c|c|c|c|}
\hline \multirow{3}{*}{ Treatments } & \multicolumn{12}{|c|}{$1^{\text {st }}$ season } \\
\hline & \multicolumn{3}{|c|}{ Control } & \multicolumn{3}{|c|}{$\mathrm{HCO}_{3}^{-}\left(5 \mathrm{meq} \mathrm{L}^{-1}\right)$} & \multicolumn{3}{|c|}{$\mathrm{HCO}_{3}^{-}\left(10 \mathrm{meq} \mathrm{L}^{-1}\right)$} & \multicolumn{3}{|c|}{$\mathrm{HCO}_{3}{ }^{-}\left(15 \mathrm{meq} \mathrm{L}^{-1}\right)$} \\
\hline & $\mathrm{OM}_{0}$ & $\mathrm{OM}_{1}$ & $\mathrm{OM}_{2}$ & $\mathrm{OM}_{0}$ & $\mathrm{OM}_{1}$ & $\mathrm{OM}_{2}$ & $\mathrm{OM}_{0}$ & $\mathrm{OM}_{1}$ & $\mathrm{OM}_{2}$ & $\mathrm{OM}_{0}$ & $\mathrm{OM}_{1}$ & $\mathrm{OM}_{2}$ \\
\hline $\mathbf{S}_{0}$ & 1.17 & 2.10 & 2.22 & 1.16 & 2.05 & 2.21 & 0.92 & 1.46 & 1.50 & 0.50 & 0.74 & 0.86 \\
\hline$S_{1}$ & 1.51 & 2.20 & 2.36 & 1.49 & 2.17 & 2.35 & 0.98 & 1.47 & 1.62 & 0.55 & 0.88 & 0.93 \\
\hline $\mathbf{S}_{2}$ & 1.94 & 2.25 & 2.45 & 1.91 & 2.24 & 2.44 & 1.10 & 1.51 & 1.70 & 0.68 & 0.91 & 0.97 \\
\hline LSD at 0.05 & \multicolumn{12}{|c|}{0.28} \\
\hline & \multicolumn{12}{|c|}{$2^{\text {nd }}$ season } \\
\hline $\mathbf{S}_{0}$ & 0.80 & 0.84 & 0.85 & 0.51 & 0.62 & 0.71 & 0.50 & 0.52 & 0.71 & 0.38 & 0.39 & 0.41 \\
\hline $\mathbf{S}_{1}$ & 0.86 & 0.93 & 0.94 & 0.56 & 0.69 & 0.82 & 0.56 & 0.68 & 0.81 & 0.53 & 0.64 & 0.71 \\
\hline$S_{2}$ & 0.94 & 1.04 & 1.26 & 0.64 & 0.75 & 1.11 & 0.63 & 0.72 & 0.86 & 0.60 & 0.70 & 0.77 \\
\hline at & \\
\hline
\end{tabular}

Table 6: Straw yields of wheat (ton fed $^{-1}$ ) as affected by bicarbonate, organic manure and sulphur application during the two studied seasons.

\begin{tabular}{|c|c|c|c|c|c|c|c|c|c|c|c|c|}
\hline \multirow{3}{*}{ Treatments } & \multicolumn{12}{|c|}{$1^{\text {st }}$ season } \\
\hline & \multicolumn{3}{|c|}{ Control } & \multicolumn{3}{|c|}{$\mathrm{HCO}_{3}^{-}\left(5 \mathrm{meq} \mathrm{L}^{-1}\right)$} & \multicolumn{3}{|c|}{$\mathrm{HCO}_{3}^{-}\left(10 \mathrm{meq} \mathrm{L}^{-1}\right)$} & \multicolumn{3}{|c|}{$\mathrm{HCO}_{3}{ }^{-}\left(15 \mathrm{meq} \mathrm{L}^{-1}\right)$} \\
\hline & $\mathrm{OM}_{0}$ & $\mathrm{OM}_{1}$ & $\mathrm{OM}_{2}$ & $\mathrm{OM}_{0}$ & $\mathrm{OM}_{1}$ & $\mathrm{OM}_{2}$ & $\mathrm{OM}_{0}$ & $\mathrm{OM}_{1}$ & $\mathrm{OM}_{2}$ & $\mathrm{OM}_{0}$ & $\mathrm{OM}_{1}$ & $\mathrm{OM}_{2}$ \\
\hline $\mathrm{S}_{0}$ & 2.65 & 2.96 & 3.46 & 2.61 & 2.69 & 2.80 & 1.83 & 2.12 & 2.25 & 1.65 & 1.70 & 1.97 \\
\hline S1 & 3.63 & 4.27 & 4.62 & 2.74 & 3.46 & 4.15 & 2.12 & 2.24 & 2.28 & 1.68 & 2.06 & 2.10 \\
\hline S2 & 4.15 & 4.59 & 5.28 & 3.30 & 4.07 & 4.18 & 2.15 & 2.32 & 2.90 & 1.75 & 2.25 & 2.56 \\
\hline LSD at 0.05 & \multicolumn{12}{|c|}{0.78} \\
\hline & \multicolumn{12}{|c|}{$2^{\text {nd }}$ season } \\
\hline $\mathrm{S}_{0}$ & 1.76 & 1.90 & 2.79 & 1.52 & 1.78 & 1.91 & 1.35 & 1.51 & 1.61 & 1.10 & 1.15 & 1.57 \\
\hline $\mathrm{S}_{1}$ & 1.94 & 2.34 & 2.88 & 1.90 & 2.06 & 2.62 & 1.88 & 2.06 & 2.39 & 1.26 & 1.67 & 2.03 \\
\hline $\mathrm{S}_{2}$ & 2.40 & 2.71 & 2.98 & 2.27 & 2.59 & 2.78 & 2.18 & 2.54 & 2.64 & 1.56 & 2.24 & 2.34 \\
\hline SD at 0.05 & \multicolumn{12}{|c|}{0.69} \\
\hline
\end{tabular}

The second season data (2000-2001) show that there is sharply decreasing trend was noticed in grains yield. This may be due to bicarbonate salt accumulation. The treatment of $\left(\mathrm{HCO}_{3}\right)_{1} \mathrm{OM}_{2} \mathrm{~S}_{2}$ was the best treatment, but from economic point of view the best treatment was $\left(\mathrm{HCO}_{3}\right)_{2} \mathrm{OM}_{1} \mathrm{~S}_{2}$. The 
Alaga, M. D. et al.

bicarbonate concentration at 10 and $15 \mathrm{meqL}^{-1}$ had harmful negatively effect on the yield for both grains and straw.

The reduction in the yield of plant may be due to the following reasons, a) Adverse effect of $\mathrm{HCO}_{3}$ - on plant metabolic processes; b) Disturbance of nutrients balance; and C) Excess of $\left(\mathrm{HCO}_{3}^{-}\right)$induce of $\mathrm{CO}_{3}^{--}$ions, which react with free soluble $\mathrm{Zn}^{++}$in soil solution and induce chlorosis. Similar results were obtained by Mengle et al. (1984).

Sulphur was referred to its influence on reducing soil $\mathrm{pH}$, improving soil structure and increasing the availability of certain plant nutrients (El-Shall et al., 1987 and Aziz, 1998).

With respect to available micronutrients in soil, Figs 1 to 3 show that the highest values of available $\mathrm{Fe}, \mathrm{Mn}$ and $\mathrm{Zn}$ were obtained in case of $\mathrm{OM}_{2} \mathrm{~S}_{2}$ at all treatments of $\mathrm{HCO}_{3}{ }^{-}$in saline irrigation water. This may be due to the nutrients content of FYM and the different acids, which were produced from decomposition of FYM and may decrease soil $\mathrm{pH}$. Sulphur application also may have a role in decrease soil $\mathrm{pH}$ and increasing micronutrients availability.
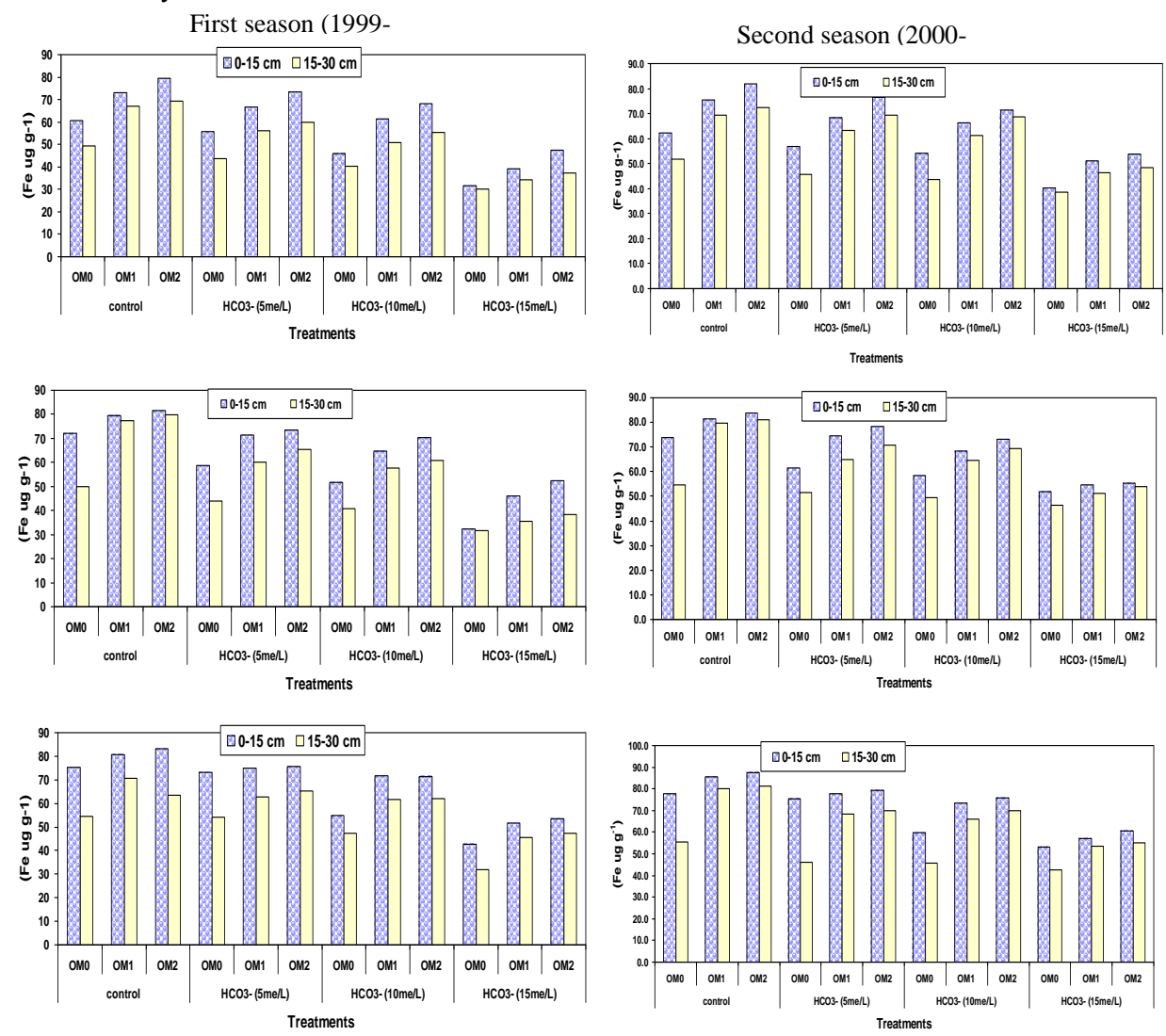

Fig. 1: Available Fe in (mg kg soil-1) as affected by bicarbonate, organic manure and sulphur application. 

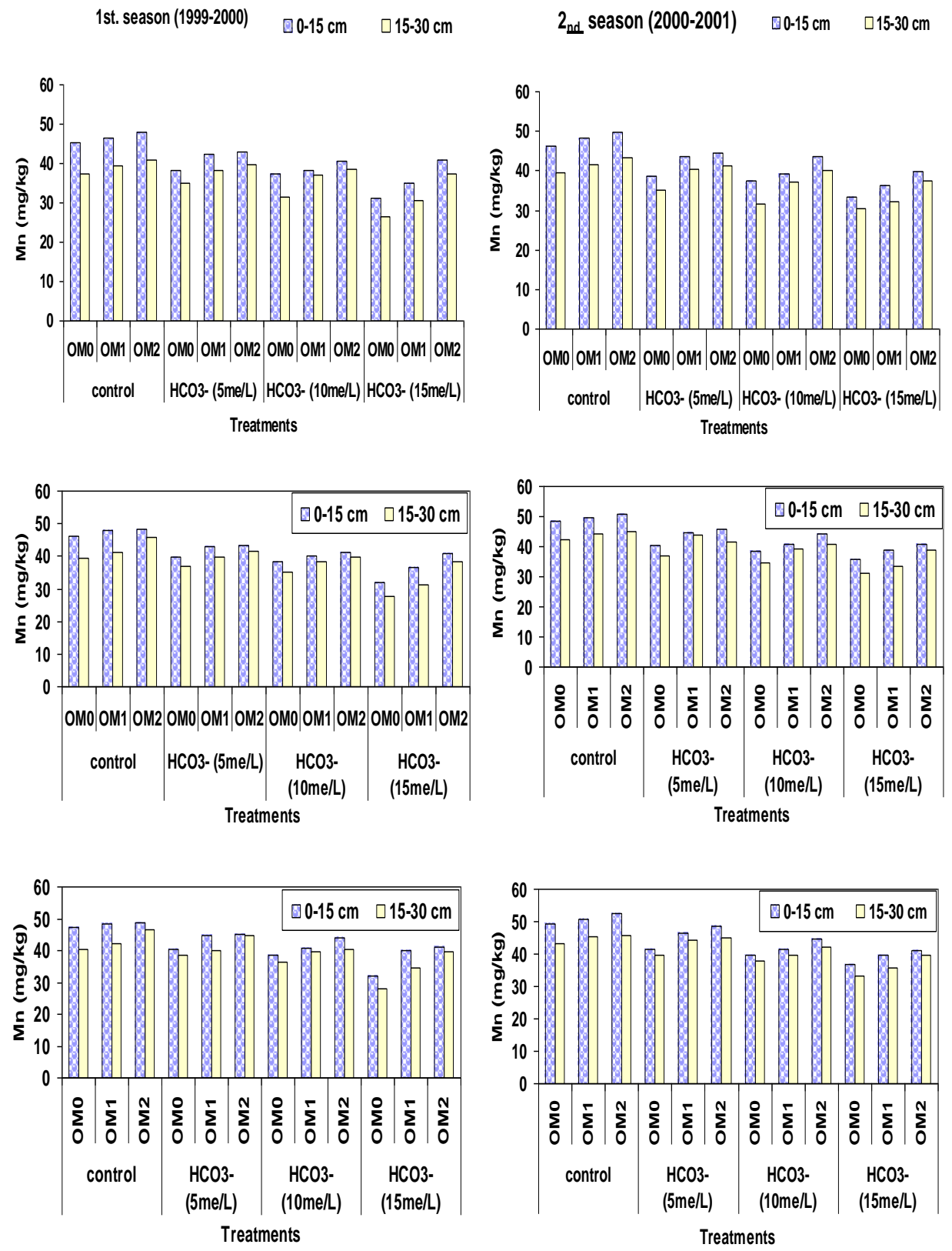

Fig 2: Available $\mathrm{Mn}$ in ( $\left.\mathrm{mg} \mathrm{kg} \mathrm{soil}^{-1}\right)$ as affected by bicarbonate, organic manure and sulphur application. 
Alaga, M. D. et al.
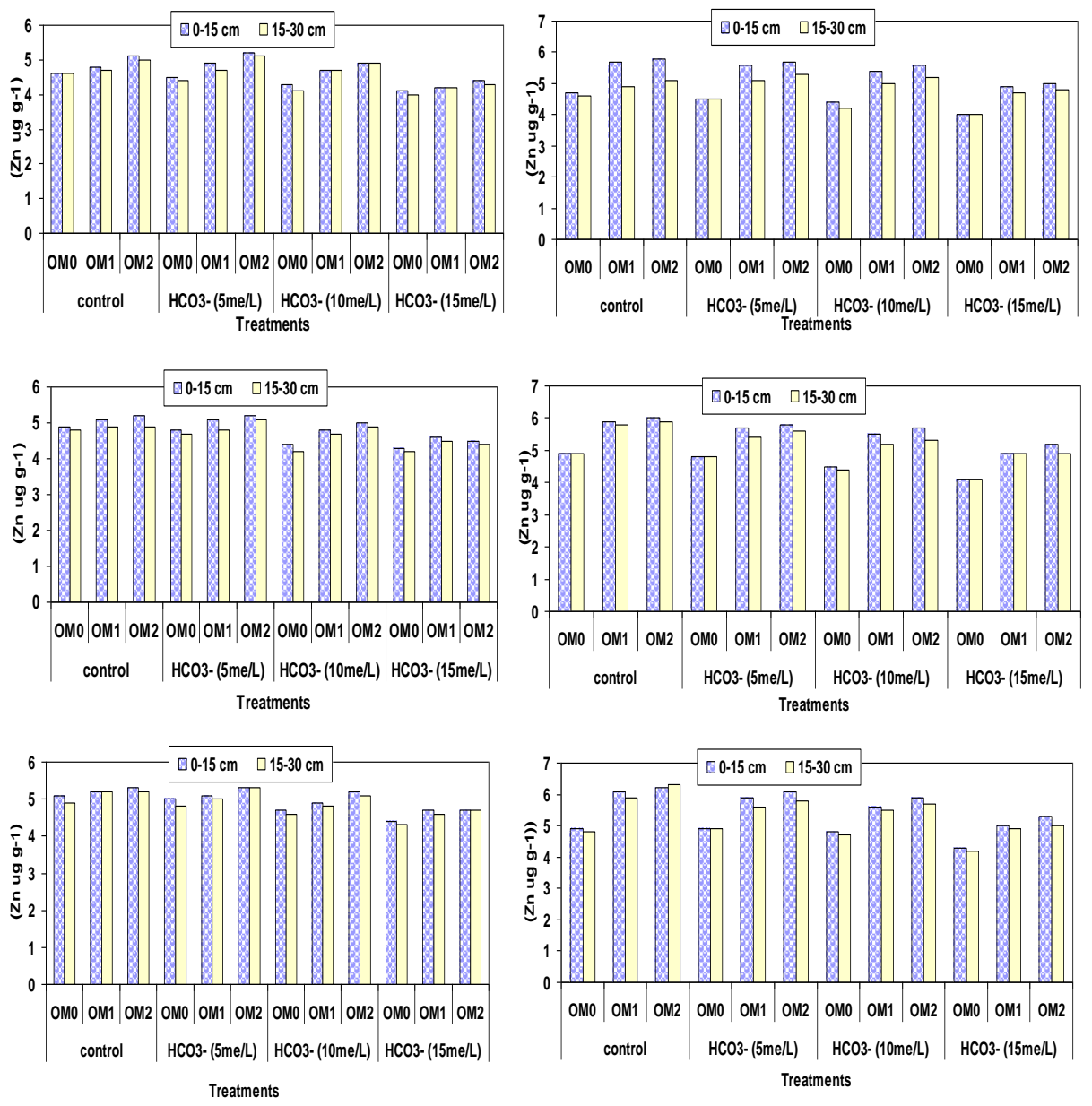

Fig. 3: Available $\mathrm{Zn}$ in ( $\mathrm{mg} \mathrm{kg} \mathrm{soil}^{-1}$ ) as affected by bicarbonate, organic manure and sulphur application.

\section{Conclusion}

Grains and straw yield of wheat was the highest value in case of $\left(\mathrm{HCO}_{3}\right)_{1} \mathrm{OM}_{2} \mathrm{~S}_{2}$ in the first and second seasons. The harmful negatively effect of $\mathrm{HCO}_{3}$ ions was clear through the second season. This due to $\mathrm{HCO}_{3}$ salt accumulation at 10 and $15 \mathrm{meqL}^{-1}$.

From the economic point of view the best treatment was $\left(\mathrm{HCO}_{3}\right)_{2}$ $\mathrm{OM}_{1} \mathrm{~S}_{2}$. Available micronutrients in soil raised with increasing $\mathrm{FYM}$ and $\mathrm{S}$ rates.

The highest values of available $\mathrm{Fe}, \mathrm{Mn}$ and $\mathrm{Zn}$ were in case of $\mathrm{OM} 2 \mathrm{~S} 2$ at all treatments of $\mathrm{HCO}_{3}{ }_{3}$. 


\section{REFERENCES}

Aich, A. C., A. H. M. Ahmed, and R. Mandal (1997). Impact of organic matter lime and gypsum on grain yield of wheat in salt affected soil irrigated with different grades of brackish water. Journal of physiological research. 10: 1-2, 79-84

Aziz, M. A., M. F. A. Sallam, A. M. El-Gendy and M. A. El-Moniem(1998). Effect of natural soil conditioners and irrigation conditions on some chemical properties of sandy soils of Inshas and cucumber yield. Egyptian Journal of Soil Science. 38:1-4, 377-411.

Chapman, H. D and D. F. Pratt (1961). Methods of Analysis for Soil, Plants and Water . Univ. of California, Division of Agric. Science.

Clarck, D. R., C. J. Green, V. G. Allen and C. P. Brown (1999) Effect of salinity in irrigation water on forage sorghum and soil chemical. Journal-of-plantNutrition. 22: (12), 1905-1920.

El-Shall, A., M. Wassif., M. Hilal and I. El-Bagouri (1987). Response of barley to sulpher application in a calcareous soil under saline water. DesertInstitute-Bulletin, Egypt. 37, 1, 117-130.

Frie, E; K. Peyer and E. shatg (1964). Determination of phosphorus by ascorbic acid. Schw landwritschaft, Forschung Heft. 3.318:328

Gomez, K. A. and A. A. Gomez (1984). "Statistical Procedures for Agricultural Research". 2nd Ed. John Wiely and Sons New York, pp. 680.Inc.

Jackson, M. L. (1967). Soil Chemical Analysis Constable \& Co., Ltd., London.

Lindsay and Norvell, (1978). Development of a DTPA soil test for Fe, Mn, Zn and Cu. Soil Sci. Amer. Proc. 42:421-428.

Mengel, K., M. Th. Breininger and W. Bubl (1984). Bicarbonate, the most important factor inducing iron cholorosis in Vine grapes on calcareous soil. Plant and Soil. 81: $333-344$.

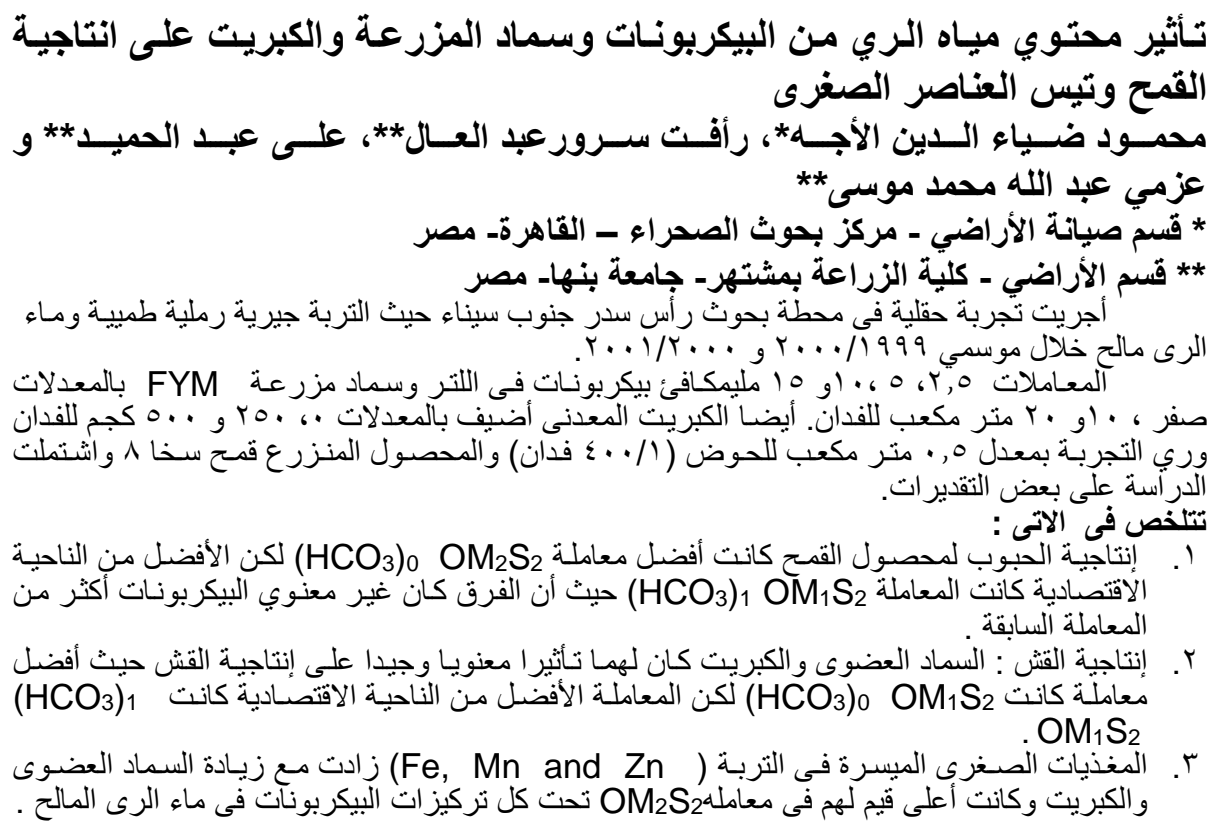

